\title{
Effects of Different Selenium Concentrations on Physiology of Prunus davidiana Seedlings
}

\author{
Liu Yang, Qinyuan Li, Junjiang Shu, Ling Xiao, Xinyu Gao and Ming'an Liao* \\ College of Horticulture, Sichuan Agricultural University, Chengdu, Sichuan, 611130, China
}

\begin{abstract}
To study the effects of selenium on physiology, Prunus davidiana seedlings were treated with the irrigation of different selenium concentrations solution. The result showed that the photosynthetic pigment content was relatively higher at selenium concentrations of $0,0.05$ and $0.1 \mathrm{mg} / \mathrm{L}$ except for carotenoid content which was the highest at $0.1 \mathrm{mg} / \mathrm{L}$ but the lowest in control seedlings. In terms of antioxidant enzyme activity, the activities of peroxidase (POD), catalase (CAT) and superoxide dismutase (SOD) in selenium-treated seedlings were all higher than that in control seedlings and especially at the selenium concentration of $1 \mathrm{mg} / \mathrm{L}$. The soluble protein content accumulated most at $0.25 \mathrm{mg} / \mathrm{L}$ selenium concentration. The content of malondialdehyde (MDA), as membrane lipid peroxidation index, was the lowest at selenium concentration of $0.5 \mathrm{mg} / \mathrm{L}$. In a word, irrigating lower selenium concentrations could increase the photosynthetic pigment content and higher selenium concentrations enhanced the antioxidant enzyme activity to increase cell protection and kept the $P$. davidiana seedlings good growth and resistance to adverse environments.
\end{abstract}

\section{Introduction}

Selenium, a trace element essential for people's heath, has a wide range of pleiotropic effects of good antioxidant capacity, immune function, an anti-cancer and incorporated into selenoproteins to make difference [1-2]. Selenium was capable of prolonging the green retention time of lettuce leaves and increases the content of proline to enhance the resistance of plants [3-4]. With the increase of exogenous selenium concentrations, the activity of antioxidant enzymes (SOD, POD and CAT) in tomato seedlings significantly increased and the content of MDA gradually decreased [5]. There are also many studies on selenium in fruit trees. The previous researches report that selenium treatments can increase photosynthetic rate, chlorophyll content and disease resistance of grape seedlings [6]. It also works on walnut and persimmon trees [7]. In this experiment, irrigating selenium solution was used to study the changes of physiology on Prunus davidiana seedlings.

Speaking of $P$. davidiana, it belongs to the genus peach of Rosaceae and has good drought resistance, salt and alkali resistance, good grafting affinity for other significant researches [8]. There were few studies on selenium of $P$. davidiana and it is necessary to conduct a research for application of selenium in $P$. davidiana seedlings.

\section{Materials and methods}

\section{$2.1 \quad$ Materials}

P. davidiana seeds, purchased from a market in Chengdu, Sichuan, China, were used as materials to reveal the effects of physiology in $P$. davidiana seedlings by irrigating different concentrations of selenium solution. Meanwhile, the Hoagland nutrient solution was needed for solution culture experiment, which was bought online.

\subsection{Experimental design}

The experiment was conducted in a greenhouse at the Chengdu campus of Sichuan Agricultural University from August to September 2019. Then, $P$. davidiana seeds were seeded into perlite which was placed in climate chamber for sprouting and irrigated with Hoagland nutrient solution in August 2019. Nine uniformly growing $P$. davidiana seedlings were transplanted into a plug for solution culture and irrigated Hoagland nutrient solution with different selenium concentrations $(0,0.05,0.1,0.25,0.5,1$ and $2 \mathrm{mg} / \mathrm{L})$ every 3 days, when $P$. davidiana seedlings grew to a height of $10 \mathrm{~cm}$. Each treatment repeated for three times.

After one month with selenium treatments, the mature leaves from the top of $P$. davidiana seedlings were collected for the assay of photosynthetic pigment of chlorophyll a, chlorophyll b, carotenoid and total chlorophyll, the antioxidant enzyme [superoxide dismutase (SOD), peroxidase (POD) and catalase (CAT)] activity, the osmotic adjuster of the soluble protein content and the malondialdehyde (MDA) content as described by Hao et al [9]. By measuring the above date, the effects of selenium solutions on physiological status

$\overline{\text { *Corresponding author's e-mail: lman@sicau.edu.cn }}$ 
of $P$. davidiana seedlings were more clearly and knew more the characteristics of selenium in pomology.

\subsection{Statistical analyses}

Statistical analyses were conducted to use statistical software of SPSS 17.0. Date was analyzed by one-way ANOVA with least significant difference at 5\% confidence level.

\section{Results and discussion}

\subsection{The photosynthetic pigment content in $\mathbf{P}$. davidiana seedlings}

Table 1. Photosynthetic pigment content in P. davidiana seedlings.

\begin{tabular}{cccccc}
\hline $\begin{array}{c}\text { Treatments } \\
(\mathrm{mg} / \mathrm{L})\end{array}$ & $\begin{array}{c}\text { Chlorophyll a } \\
(\mathrm{mg} / \mathrm{g})\end{array}$ & $\begin{array}{c}\text { Chlorophyll b } \\
(\mathrm{mg} / \mathrm{g})\end{array}$ & $\begin{array}{c}\text { Carotenoid } \\
(\mathrm{mg} / \mathrm{g})\end{array}$ & $\begin{array}{c}\text { Total chlorophyll } \\
(\mathrm{mg} / \mathrm{g})\end{array}$ & Chlorophyll a/b \\
\hline 0 & $2.605 \pm 0.092 \mathrm{a}$ & $0.973 \pm 0.014 \mathrm{a}$ & $0.521 \pm 0.017 \mathrm{c}$ & $3.578 \pm 0.098 \mathrm{a}$ & $2.678 \pm 0.092 \mathrm{c}$ \\
0.05 & $2.633 \pm 0.048 \mathrm{a}$ & $0.958 \pm 0.028 \mathrm{a}$ & $0.540 \pm 0.014 \mathrm{c}$ & $3.592 \pm 0.075 \mathrm{a}$ & $2.747 \pm 0.035 \mathrm{c}$ \\
0.1 & $2.629 \pm 0.035 \mathrm{a}$ & $0.940 \pm 0.012 \mathrm{a}$ & $0.664 \pm 0.015 \mathrm{a}$ & $3.570 \pm 0.029 \mathrm{a}$ & $2.797 \pm 0.066 \mathrm{c}$ \\
0.25 & $2.498 \pm 0.043 \mathrm{~b}$ & $0.890 \pm 0.009 \mathrm{~b}$ & $0.583 \pm 0.009 \mathrm{~b}$ & $3.388 \pm 0.044 \mathrm{~b}$ & $2.806 \pm 0.057 \mathrm{c}$ \\
0.5 & $2.476 \pm 0.039 \mathrm{~b}$ & $0.836 \pm 0.032 \mathrm{c}$ & $0.537 \pm 0.014 \mathrm{c}$ & $3.312 \pm 0.071 \mathrm{bc}$ & $2.964 \pm 0.065 \mathrm{~b}$ \\
1 & $2.361 \pm 0.032 \mathrm{c}$ & $0.856 \pm 0.029 \mathrm{c}$ & $0.568 \pm 0.016 \mathrm{~b}$ & $3.217 \pm 0.050 \mathrm{c}$ & $2.761 \pm 0.089 \mathrm{c}$ \\
2 & $2.352 \pm 0.089 \mathrm{c}$ & $0.712 \pm 0.026 \mathrm{~d}$ & $0.567 \pm 0.029 \mathrm{~b}$ & $3.064 \pm 0.102 \mathrm{~d}$ & $3.307 \pm 0.136 \mathrm{a}$ \\
\hline
\end{tabular}

Values are means $( \pm \mathrm{SE})$ of 3 replicate pots. Different lowercase letters indicated significant differences among treatments at 0.05 levels.

The photosynthetic pigment content of chlorophyll a, chlorophyll $\mathrm{b}$ and the total chlorophyll had no significant difference $(p>0.05)$ at selenium concentrations of 0 , 0.05 and $0.1 \mathrm{mg} / \mathrm{L}$ and was the highest at $0.05 \mathrm{mg} / \mathrm{L}$ (Table 1). Then increasing the selenium concentration up to $2 \mathrm{mg} / \mathrm{L}$, the content of chlorophyll a and total chlorophyll began to gradually fall. At $0.1 \mathrm{mg} / \mathrm{L}$ selenium concentration, the carotenoid content was the highest but the lowest in control $P$. davidiana seedlings. For the chlorophyll $\mathrm{a} / \mathrm{b}$ ratio of seedlings, it had no striking difference $(p>0.05)$ at selenium concentrations of $0,0.05,0.1,0.25$ and $1 \mathrm{mg} / \mathrm{L}$. The ratio was higher at $2 \mathrm{mg} / \mathrm{L}$ selenium concentration than other treated or control treatments.

\subsection{Antioxidant enzyme activity and osmotic adjuster content of $P$. davidiana seedlings}

Irrigating different selenium concentrations could increase antioxidant enzyme activities of POD, CAT and SOD compared with control treatment (Table 2). Increasing selenium concentration from $0.05 \mathrm{mg} / \mathrm{L}$ to 1 $\mathrm{mg} / \mathrm{L}$, the activity of POD, CAT and SOD were always increased. At selenium concentration of $2 \mathrm{mg} / \mathrm{L}$, the activity began to decrease. In terms of the osmotic adjuster content, the soluble protein content was all relatively lower at selenium concentrations of $0,0.05$ and $0.1 \mathrm{mg} / \mathrm{L}$ and peaked at $0.25 \mathrm{mg} / \mathrm{L}$ selenium concentration. For the content of MDA, there was no significant difference $(p>0.05)$ among the irrigation of 0 , 0.05 and $0.1 \mathrm{mg} / \mathrm{L}$ selenium concentrations and they were all higher than other treatments. At selenium concentration of $0.5 \mathrm{mg} / \mathrm{L}$, the MDA content was the lowest and it fitted with the result of antioxidant enzyme activity.

Table 2. Antioxidant enzyme activity and osmotic adjuster content of $P$. davidiana seedlings.

\begin{tabular}{cccccc}
\hline $\begin{array}{c}\text { Treatments } \\
(\mathrm{mg} / \mathrm{L})\end{array}$ & $\begin{array}{c}\text { POD activity } \\
(\mathrm{U} / \mathrm{g} / \mathrm{min}))\end{array}$ & $\begin{array}{c}\text { CAT activity } \\
(\mathrm{mg} / \mathrm{g} / \mathrm{min})\end{array}$ & $\begin{array}{c}\text { SOD activity } \\
(\mathrm{U} / \mathrm{g})\end{array}$ & $\begin{array}{c}\text { Soluble protein content } \\
(\mathrm{mg} / \mathrm{g})\end{array}$ & $\begin{array}{c}\text { MDA content } \\
(\mu \mathrm{mol} / \mathrm{kg})\end{array}$ \\
\hline 0 & $16.31 \pm 0.685 \mathrm{e}$ & $0.912 \pm 0.022 \mathrm{~g}$ & $116.0 \pm 4.448 \mathrm{f}$ & $10.92 \pm 0.868 \mathrm{c}$ & $16.29 \pm 0.386 \mathrm{a}$ \\
0.05 & $17.47 \pm 0.871 \mathrm{e}$ & $1.577 \pm 0.026 \mathrm{f}$ & $121.0 \pm 2.141 \mathrm{f}$ & $6.128 \pm 0.228 \mathrm{~d}$ & $16.55 \pm 0.524 \mathrm{a}$ \\
0.1 & $20.83 \pm 1.062 \mathrm{e}$ & $2.114 \pm 0.087 \mathrm{e}$ & $148.3 \pm 2.746 \mathrm{e}$ & $11.30 \pm 0.756 \mathrm{c}$ & $15.99 \pm 0.344 \mathrm{a}$ \\
0.25 & $115.4 \pm 3.606 \mathrm{~d}$ & $3.064 \pm 0.098 \mathrm{c}$ & $158.0 \pm 4.632 \mathrm{~d}$ & $20.56 \pm 0.946 \mathrm{a}$ & $13.09 \pm 0.211 \mathrm{c}$ \\
0.5 & $241.1 \pm 6.319 \mathrm{~b}$ & $4.603 \pm 0.133 \mathrm{~b}$ & $232.7 \pm 9.319 \mathrm{~b}$ & $15.91 \pm 0.254 \mathrm{~b}$ & $10.86 \pm 0.373 \mathrm{e}$ \\
1 & $469.0 \pm 6.818 \mathrm{a}$ & $5.582 \pm 0.115 \mathrm{a}$ & $244.4 \pm 5.534 \mathrm{a}$ & $16.64 \pm 0.557 \mathrm{~b}$ & $12.31 \pm 0.173 \mathrm{~d}$ \\
2 & $148.7 \pm 2.816 \mathrm{c}$ & $2.332 \pm 0.056 \mathrm{~d}$ & $186.8 \pm 6.095 \mathrm{c}$ & $11.35 \pm 0.525 \mathrm{c}$ & $15.19 \pm 0.244 \mathrm{~b}$ \\
\hline
\end{tabular}

Values are means $( \pm \mathrm{SE})$ of 3 replicate pots. Different lowercase letters indicated significant differences among treatments at 0.05 levels. 


\section{Conclusions}

In this experiment, the results showed that the effects of antioxidant enzyme activity and photosynthetic pigment content on $P$. davidiana seedlings by irrigating Hoagland nutrient solution with different selenium concentrations. The photosynthetic pigment content was all higher at selenium concentrations of $0,0.05$ and $0.1 \mathrm{mg} / \mathrm{L}$ except for the carotenoid content and the lowest at $2 \mathrm{mg} / \mathrm{L}$. The chlorophyll $\mathrm{a} / \mathrm{b}$ ratio in treated $P$. davidiana seedlings was all higher than that in control seedlings. Irrigating selenium concentrations increased antioxidant enzyme activity of POD, CAT and SOD. In selenium treatments, $1 \mathrm{mg} / \mathrm{L}$ selenium concentration was the best one for increasing activity. Similarly, the MDA content was lower at 0.5 and $1 \mathrm{mg} / \mathrm{L}$ which was good for the growth and resistance of $P$. davidiana seedlings.

\section{Acknowledgments}

This work was financially supported by the Application Infrastructure Project of Science and Technology Department of Sichuan Province (2016JY0258).

\section{References}

1. Xu, L.L., Xu, Y.M. (2016) Study on trace element selenium and human health. Agric. Tech. Ser., 33: 85-86.

2. Rayman, M.P. (2012) Selenium and human health. The Lancet, 379: 1256-1268.

3. Xue, T.L., Hartikainen, H., Piironen, V. (2001) Antioxidative and growth-promoting effect of selenium in senescing lettuce. Plant Soil, 23: 5561.

4. Zhang, C., Wu, Y.X., Peng, Z.K. (2002) Effects of selenium on leaf pigment of rapeseed at seedling stage. J. Hubei Univ. Nat. (Nat. Sci.), 20: 63-65.

5. Han, G.Y., Li, J., Song, M.M., Liu, H.Y. (2010) Effects of selenium on germination and antioxidant enzyme system of processed tomato seeds under salt stress. J. Shihezi Univ. (Nat. Sci.), 28: 422-426.

6. Wang, H.B., Wang, X.D., Yao, X.Y., Xie, J.M., Wang, B.L., Wei, C.C. (2011) Application of amino acid selenium leaf fertilizer on rose grape. Gra. Win. Home Abro., pp: 47-49.

7. Wu, G.L., Liu, Q.L., Liu, H., Yan, H.J., Wang, L.P. (2004) Effects of auto-dripping of micronutrient fertilizers on physiology and fruit quality of fruit trees. J. Appl. Environ. Bio., 10: 154-157.

8. Choi, J.S., Woo, W.S., Young, H.S., Park, J.H. (1990) Phytochemical study on Prunus davidiana. Arch. Pha. Res., 13: 374-378.
9. Hao, Z.B., Cang, J., Xu, Z. (2004) Plant physiology experiment. Harbin Institute of Technology Press, Haibin, China. 